\title{
Influence of high-power electromagnetic pulses on surface state and floatability of carbonate-bearing pyrite and arsenopyrite*.
}

\author{
Valentine A. Chanturiya ${ }^{1}$, Inna V. Filippova ${ }^{2,3}$, Lev O. Filippov ${ }^{2,}$, M.V. Ryazantseva ${ }^{1,2}$, M.Mullet $^{3}$ \\ ${ }^{I}$ Institute of Comprehensive Exploitation of Mineral Resources, Russian Academy of Sciences (IPKON RAS) \\ ${ }^{2}$ STU "Moscou Institute of Steel and alloys", 4 av Leninsky, Moscou, Russia \\ ${ }^{3}$ Laboratoire Environnement et Minéralurgie(LEM), Nancy-Université, CNRS, Rue du Doyen Roubault B.P. 40 \\ F-54501 Vandouvre lès Nancy, France
}

\section{Introduction}

Many works are devoted now to research and development of non-traditional, highly efficient disintegration technologies for resistant ores, with emphasis on the problem of increasing the contrast of processing characteristics of minerals [1,2,3,4].

The method with usage of high power electromagnetic pulses (HPEMP) for the selective disintegration of the fine-grained mineral complexes, for the disclosure of the precious metals inclusions and them extraction in productive solutions was developed [1,2].

It was determined, that the electric breakdown channels are localised along the areas of the lowered electric strength with the conductive gold particles at the disclosing of the gold in pyrite (arsenopyirite). The possibility of the sulphide matrix opening and increasing of gold particles $(0.01-0.001 \mu \mathrm{m})$ extraction in the productive solutions (from $15-50 \%$ until $85 \%$ ) was determined in the result of the experimental work [1]. It was supposed the basic influence effect is caused by the creation of micro channels and micro cracks going from the surface of the particle towards the precious metal inclusion [1,2].

On the basis of these results it was supported that the influence of electromagnetic pulses on mineral complexes will change the hydrophilic and hydrophobic properties of mineral surface. The aim of this study is revealing of minerals surface properties and phase composition changing under the high power electromagnetic pulses influence.

\section{Experimental methods and characteristics or research objects}

In this study a two natural mineral samples were used: pyrite from Darasun ore field and arsenopyrite of unknown origin. Size fraction was $100+50 \mu \mathrm{m}$.

The treatment by the high power electromagnetic pulses of the minerals was carried out on a laboratory unit by the series of pulses (number of pulses from 1000 to 15000) with nanosecond wave front and with duration 5-30 ns, amplitude of electrical field component is up to $30 \mathrm{KV}$, frequency of pulses and pulses repetition frequency is $100 \mathrm{~Hz}$.

The dry and the wet minerals samples were used for the treatment $\left(\mathrm{MeS} / \mathrm{H}_{2} \mathrm{O}=10 / 3\right)$. After treatment the wet samples were dried in nitrogen atmosphere. All samples were kept until the analysis in nitrogen atmosphere.

X-Ray photoelectron spectra were obtained with KRATOS Axis Ultra spectrometer. Monochromatized X-Rays from an $\mathrm{AlK}_{\alpha}$ anode was used. Dates treatments were done with program Vision 2.2.6 (KRATOS).

IR-spectra of minerals were obtained with usage of ISF 55 BRUKER EQUINOX 55 spectrometer in diffuse reflectance mode. XRD dates were obtained on powder samples with D8 ADVANCE (BRUKER). SEM analyses were performed using scanning electron microscope XL-30 (Philips) with an analyzer «Edax» for elemental analysis of the surface.

Microflotation tests were conducted with $1 \mathrm{~g}$ of mineral in a laboratory microcell (volume 18 $\mathrm{ml})$ using butyl potassium xanthate $(10 \mathrm{mg} / \mathrm{l})$ as collector and MIBC $(10 \mathrm{mg} / \mathrm{l})$ as frother. All tests were conducted at natural $\mathrm{pH} 7$ created by mineral suspensions. 


\section{Mineralogy of samples}

The main feature of Darasun pyrite and arsenopyrite is the presence of calcium $(0.57 \%$ in $\mathrm{FeS}_{2}$ and $0.22 \%$ in $\left.\mathrm{FeAsS}\right)$. Inclusions of $\mathrm{Cu}(\sim 1.5 \%), \mathrm{Sb}(1.1 \%), \mathrm{Pb}(0.8 \%), \mathrm{As}(0.61 \%), \mathrm{Zn}$ $(\sim 0.2 \%)$ and the traces of $\mathrm{Mn}, \mathrm{Ag}, \mathrm{Au}$ were detected in the sample of pyrite. The investigation of inclusions nature through different methods (XRD, DRIFT, SEM) shows that in the arsenopyrite calcium is bonded with calcite $\mathrm{CaCO}_{3}$. Besides dolomite $(\mathrm{Ca}, \mathrm{Mg})\left(\mathrm{CO}_{3}\right)_{2}$, siderite $\mathrm{FeCO}_{3}$, sulfates (gypsum $\mathrm{CaSO}_{4} \cdot 2 \mathrm{H}_{2} \mathrm{O}$, bassanite $\mathrm{CaSO}_{4} \cdot 0.5 \mathrm{H}_{2} \mathrm{O}$ ) are observed in the samples of pyrite. The presence of quartz $\left(\mathrm{SiO}_{2}\right)$ and aluminosilicates was detected in the both minerals.

Microanalysis of pyrite chemical composition fulfilled by the use of SEM indicated that $\mathrm{Cu}$, $\mathrm{Sb}$ and $\mathrm{As}$ are related with the inclusions of sulfides from tennantite-tetrahedrite group $\left(\mathrm{Cu}_{12} \mathrm{As}_{4} \mathrm{~S}_{13}-\mathrm{Cu}_{12} \mathrm{Sb}_{4} \mathrm{~S}_{13}\right)$ with considerable variation of $\mathrm{Cu}, \mathrm{Sb}$ and As proportion. The other inclusions of sulfide minerals in pyrite such as arsenopyrite, galena and sphalerite are in association with pyrite and minerals of tennantite-tetrahedrite group. Silver and gold is presented by the fine-grained particles and emulsion impregnation in the sulfide matrix. The weight content of $\mathrm{Ag}$ in some pyrite grains is up to $2.02 \div 2.63 \%$, and it is up to $3.81 \div 5.03 \div 7.01 \%$ for $\mathrm{Au}$. Gold containing sulfide particles have a specific, and non stoichiometric chemical composition (fig. 1).

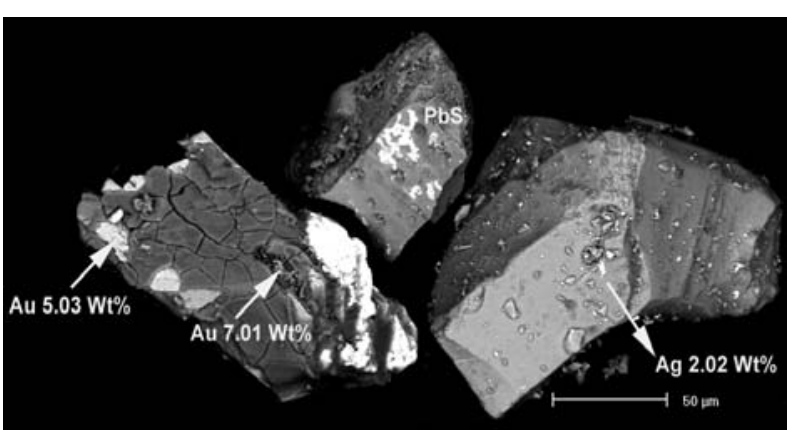

Fig.1. Photomicrography of sulfide admixture inclusion in pyrite from Darasun ore field (reflected electrons).

\section{Results and discussion}

XRD analysis of treated pyrite and arsenopyrite samples has not shown any changing of mineralogical composition after the treatment. However, the appearance of iron (III) oxides was observed on the spectra of wet treated Darasun pyrite samples at high number (15 000) of the pulses.

DRIFT showed that the surface of pyrite before the treatment was represented by mixture of $\mathrm{Fe}^{2+} / \mathrm{Fe}^{3+}$ hydrated sulfates $\left(\mathrm{nH}_{2} \mathrm{O}=7 \div 9\right)$ with the predominance of the

melanterite $\left(\mathrm{Fe}^{2+} \mathrm{SO}_{4} \cdot 7 \mathrm{H}_{2} \mathrm{O}\right)$. The week quantity of goethite and limonite $(\mathrm{FeOOH}-$ $\mathrm{FeOOH}^{*} \mathrm{nH}_{2} \mathrm{O}$ ), as well as the mixture of $\mathrm{Fe}-\mathrm{Ca}$ carbonates and the traces of calcium sulfates were detected.

After the treatment of the wet sample the surface of mineral is strongly «gypsumed» (fig. 2) as show stretching $\left(v_{\mathrm{OH}}\right) 3546-3248-3399 \mathrm{~cm}^{-1}$ and bending $\left(\delta_{\mathrm{OH}}\right) 1618-1655 \mathrm{~cm}^{-1}$ vibration of crystal water and also stretching $\left(v_{\mathrm{SO} 4}\right)$ vibration of sulfate groups at $1165,1115,604 \mathrm{~cm}^{-1}$. Simultaneously, the absorption bands of carbonate group of calcite are decreased considerably $\left(1793,1421,873,713 \mathrm{~cm}^{-1}\right)$.

The intensity increasing of stretching and bending OH-groups vibration of the sulfates crystal water is detected on the spectra of pyrite under the high number of the pulses $(\geq 10000$ pulses). In addition, the vibration of free water $\mathrm{OH}$ groups is appeared at the spectra at high number of pulses $\left(3702 \mathrm{~cm}^{-1}\right.$ and $\left.3727 \mathrm{~cm}^{-1}\right)$.

The tendencies are inversed for the dry treatment conditions. In fact, the disappearance of the peaks at $3546 \mathrm{~cm}^{-1}$ and $3248 \mathrm{~cm}^{-1}$ and of the $\mathrm{OH}$ bending vibration at $1618 \mathrm{~cm}^{-1}$ and $1655 \mathrm{~cm}^{-1}$ allow to conclude that calcium sulfate is dehydrated and gypsum is transformed in bassanite $\mathrm{CaSO}_{4} \cdot 0.5 \mathrm{H}_{2} \mathrm{O}$ and possibly in anhydrate $\mathrm{CaSO}_{4}\left(3540,3406,1155,1117,618,605 \mathrm{~cm}^{-1}\right)$ under the high number of pulses (15000 pulses). 
The transformation mechanism of $\mathrm{FeS}_{2}$ under the treatment by the high-power pulses depends on the treatment conditions (dry or wet) and besides it depends on the number of the pulses.
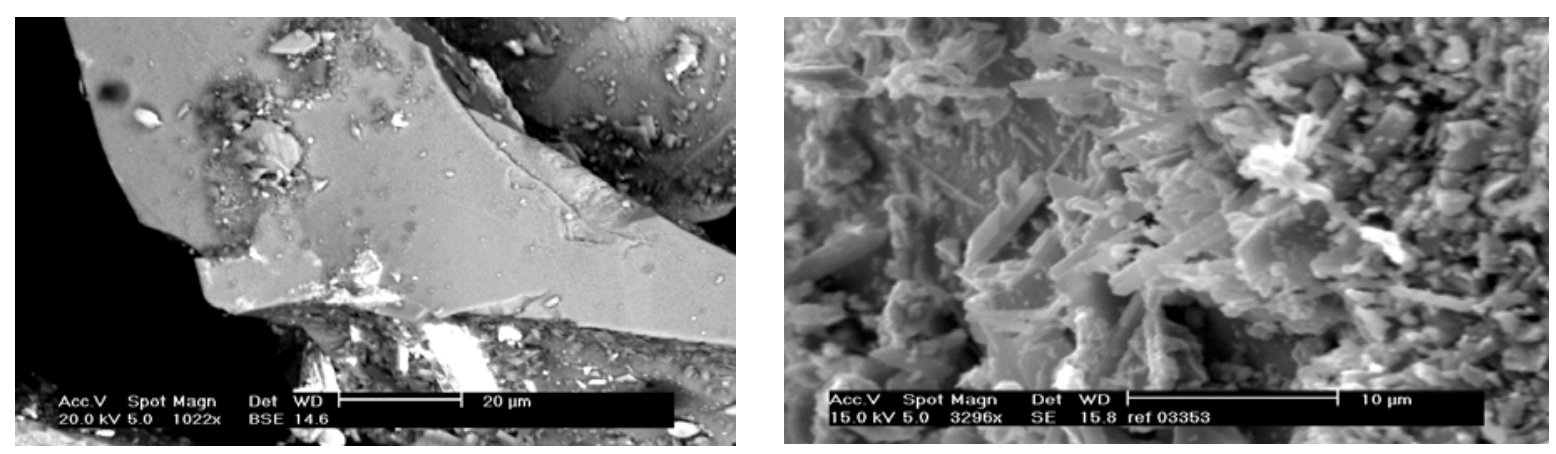

Fig.2.Photomicrography of $\mathrm{FeS}_{2}$ grains before and after treatment by electromagnetic pulses (number of treatment -15000 pulses): «gypsumed» pyrite.

The following phases were detected at 1000 pulses on the wet treatment conditions: hydrated sulfates of $\mathrm{Fe}^{3+}$ like $\left(\mathrm{Fe}_{2}\left(\mathrm{SO}_{4}\right)_{3} \cdot 7 \div 9 \mathrm{H}_{2} \mathrm{O}\right.$, hydrated sulfates like $\left.\mathrm{Fe}^{3+}\left[(\mathrm{OH})\left(\mathrm{SO}_{4}\right)\right] \cdot 4 \frac{1}{2} \mathrm{H}_{2} \mathrm{O}\right)$, oxyhydroxide $\mathrm{FeOOH}$, hematite $\mathrm{Fe}_{2} \mathrm{O}_{3}$. The mixture of $\mathrm{Fe}^{2+} / \mathrm{Fe}^{3+}$ hydrated sulfates was determined at $5000 \div 15000$ pulses: compounds like $\mathrm{Fe}^{2+} \mathrm{SO}_{4} \cdot 7 \mathrm{H}_{2} \mathrm{O}$ and $\mathrm{Fe}^{3+}\left[(\mathrm{OH})\left(\mathrm{SO}_{4}\right)\right] \cdot 4 \frac{1}{2}$ $\left.\mathrm{H}_{2} \mathrm{O}\right)$ were observed.

At 1000 pulses of dry treatment the formation of ferric hydrated sulfates simultaneously with ferrous hydrated sulfates was detected. The dry treatments at 15000 results in formation of $\mathrm{Fe}^{2+}$ hydrated sulfates. The compounds like $\mathrm{FeSO}_{4} \cdot 7 \mathrm{H}_{2} \mathrm{O}$ and $\mathrm{FeSO}_{4}(\mathrm{OH}) \cdot 3 \frac{1}{2} \mathrm{H}_{2} \mathrm{O}$ were detected.

In the case of arsenopyrite, considerable variation of DRIFT spectra profile was not detected with the increasing of number of pulses. But as in the case with pyrite, the bending vibrations of the free water molecules were observed.

XPS result shows the considerable qualitative and quantitative changes of surface layer composition of both sulfides depending on treatment conditions. The oxide-hydroxide phase of the pyrite surface increases in 30 at $\%$ in comparison with the initial sample at 1000 pulses of wet conditions. The considerable changing of the pyrite surface is not observed at 1000 pulses in dry conditions (fig. 3).
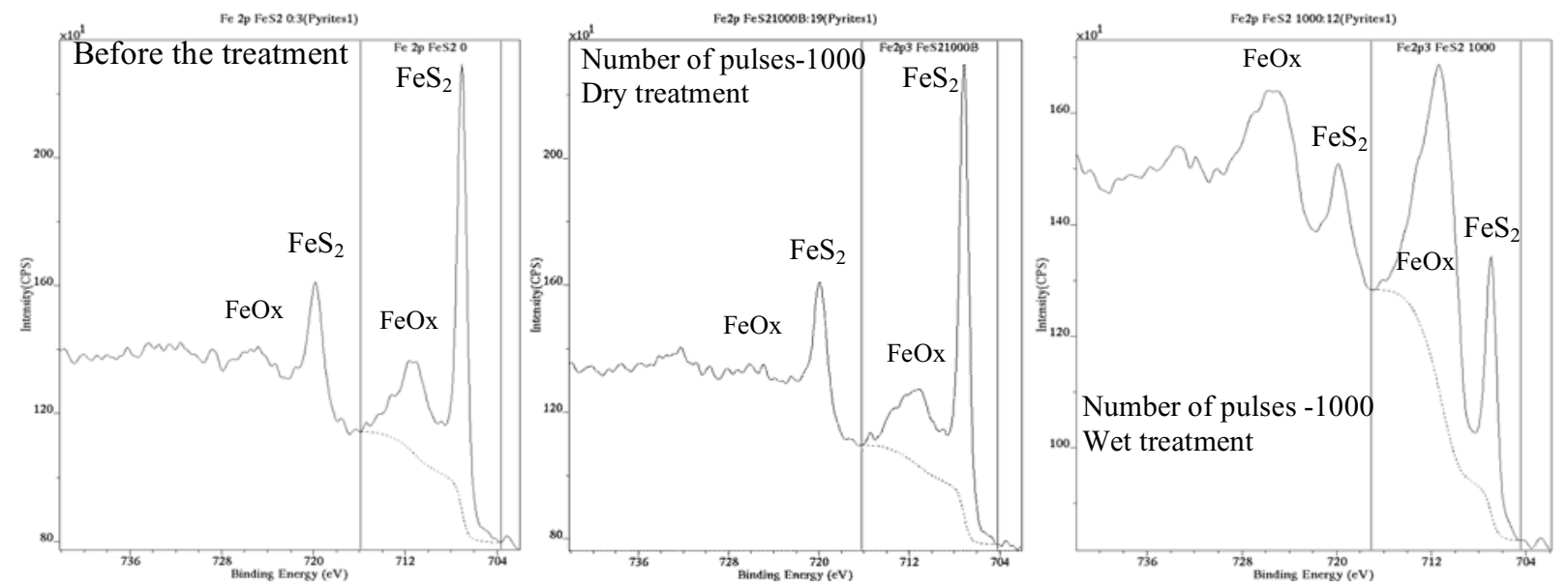

Fig.3. Fe 2p line of $\mathrm{FeS}_{2}$ XPS spectra: before the treatment and after dry and wet treatment (1000 pulses). 
Simultaneously with the formation of hydrophilic compounds (oxide-hydroxide and sulfates) oxidation of pyrite in the wet conditions is related with the formation on the surface of sulfurrich hydrophobic species.

The increasing of $\mathrm{S}^{0}$ content on the pyrite surface is 1.54 time at 1000 pulses wet treatment. At the same time on the dry conditions this parameter is 0.87 . All mentioned changes have significant influence on pyrite floatability.

The line Ca2p XPS spectra confirmed the increasing of the gypsum presence in the surface layer of mineral with the increasing of number of pulses from 1000 pulses to 15000 pulses for the wet treated samples. The quantity of $\mathrm{Ca}$ (at.\%) is increased in $2 \div 2.4$ time in comparison with the initial sample. At the spectra of pyrite it is detected also $\mathrm{Cu}$ (0.6 $\div 1.4$ at.\%), $\mathrm{Pb}(0.31$ at.\%), Si (until 3.77at.\%).

It was detected the changing of the hydrophobic-hydrophilic properties of the surface in function on treatment conditions. The increasing of Darasun pyrite floatability was obtained for the wet treatment conditions: from $46.2 \%$ for initial sample to $84.0 \%$ for the 15000 pulses (fig.4). Recovery of arsenopyrite is decreased from $57.9 \%$ (0 pulses) to $43.3 \%$ (1000 pulses) in the same condition.

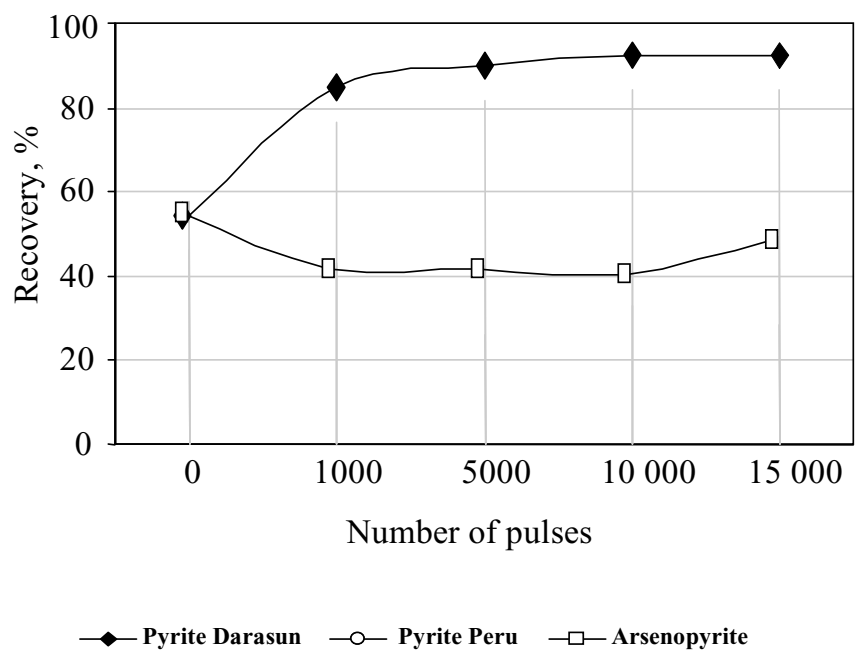

Fig. 4 Floatability of pyrite from Darasun and arsenopyrite (wet treatment) depends on number of pulses.

\section{Conclusions}

The research work shows the influence of high power electromagnetic pulses on the changing of the surface layer composition of pyrite and arsenopyrite.

The presence of the admixtures result in a formation of calcium sulfates, the quantity of calcium sulfates increase with the increasing of the number of pulses.

The work allows to identify the conditions of the selective flotation of pyrite and arsenopyrite.

\section{References}

1. V.A.Chanturia, Yu.V.Gulyaev, I.G.Bunin, V.D.Lunin, C.V.Sedelnikova. Non-traditional higly Effective Breaking-up Technology for Resistant Gold-Containing Ores and Benefication Products. Proceedings of XXII Int. Min. Proces. Congress (L. Lorenzen and D.J. Bradshaw Eds), Cape Town, South Africa, 29 september-3 october 2003, Cape Town, Documents Transformation Technologies, 2003, vol.1, pp.232-241

2. V.A.Chanturiya, I.Zh. Bunin, V.D.Lunin, Yu.V. Gulyaev, N.S. Bunina, V.A. Vdovin, P.S.Voronov, A.V.Korzhenevskii, V.A.Cherepenin. Use of high-power electromagnetic pulses in processes of disintegration and opening of rebellious gold-containing raw material. J. of Mining science 37(4) 2001.

3. N.M.Can, I.Bayraktar Effect of microwave treatment on the flotation and magnetic separation properties of pyrite, chalcopyrite, galena and sphalerite. Minerals and Metallurgical Processing 23(3) 2007.

4. S.W.Kingman, N.A. Rowson. Microwave treatment of minerls-review Minerals Engineering 11(11) 1081, (2003)

5. V.C.Farmer. The infrared spectra of minerals. Mineralogical society (1974), 427pp. 